\title{
Internal Party Democracy and the Imperative of Democratic Consolidation in Nigeria's Fourth Republic
}

\author{
DOI: $10.36108 / \mathrm{NJSA} / 6102 / 14(0240)$
}

\section{Daniel Godwin}

Department of Political Science

University of Ibadan

Ibadan, Nigeria

E-mail: godwind42@yahoo.com

\begin{abstract}
Parties are regarded as sine qua non for the organization of modern democracies, as well as for democratic consolidation. The literature that explains Nigeria's democracy since 1999 depicts infractions and instability in party politics. It is in this context that this paper maintains that the major threat to democratic consolidation in Nigeria's Fourth Republic is the absent of Internal Party Democracy (IPD). The inability of political parties to manage their internal fuss usually results in cases of defections, which portends negative consequences for democratic consolidation in Nigeria. The paper explains and provides some internal governing structures for political parties as offered by Simba. Consequently, the study historically gave an illustration of political parties in the previous republics by showing how they were bereft of internal party democracy. The paper finally calls for an urgent alternative to this kind of party politics, while the current practice should be jettisoned.
\end{abstract}

Keywords: democracy, internal party democracy, political party and democratic consolidation

\section{Introduction}

After a long spell of military despotism and sustained authoritarian rule, Nigeria's democracy was restored on 29th May, 1999, marking the Fourth Republic. Indeed Nigeria and Nigerians were full of expectations that democracy has come to stay, since its interruption in December 1983. Ironically, Nigeria's democracy continues to be faced with challenges, among which are the imposition of candidates by godfathers, money bag politics, and party indiscipline, triggered by lack of internal party democracy within political parties (Abimbola and Adesite, 2012: 46). The deficit of democratic culture displayed by political parties since the return of civil rule has contributed immensely to the challenge of democratic consolidation in Nigeria. The current scenario of defection perceived in some quarters as crosscarpeting, or party switching, has become a common phenomenon and a feature in the Nigerian politics (Mbah, 2011; Abimbola and Adesite, 2012). It is argued that democracy only strives when it is founded on strong and well organized political parties with well-defined structure (Omotola, 2002). Simba (2011) suggested that for any political party to be relevant in a democratic system, such party must imbibe the values of internal democracy. 
Consequently, political parties must have regard for such key elements as distribution of power and liberalization of decision making process. When these two elements are clearly defined in the structure and organization of a political party, then, the party is said to be on the path of internal democracy.

A cursory survey of the literature on Nigeria's political parties since 1999 reveals that they lack internal and open democratic system, wide distribution of power, and an inclusive decision making process (Agbaje, Akande and Ojo, 2007; Thurston, 2015). This trend of party politics has made it difficult for party members to contest for office of their choice, thereby, restricting members' opportunities to aspire for public office within the party of their choice. The consequence of this kind of impunity is manifested in various dimensions such as party defection, acrimony, recrimination, attrition, unduecompetition, character assassination, and generally, over heating the political atmosphere with unguarded comments.

From the foregoing, therefore, the paper interrogates the practice of internal party democracy and its implication for democratic consolidation in Nigeria's Fourth Republic. The paper shows the nexus between lack of internal party democracy and the problem of democratic consolidation in Nigeria, and it adopts the historical analytical model for its analysis. The paper is therefore divided into five modules: Introduction, conceptual clarification, intra-party democracy in Nigeria, intra-party democracy verses democratic consolidation, and conclusion.

\section{Conceptual Review \\ Democracy}

There is no an all-inclusive definition of democracy; the concept has been floated around by several scholars, right from its inception in the 5th century BC. However, to Simba (2011), a democratic system must involve the following: regular elections, open decision making process, right to vote and be voted for, respect for basic human rights, presence of a vibrant civil society, open competition for political power through viable political parties, freedom of association, separation of power, and the rule of law. As noted, a wellestablished democratic system must consist of the above elements without which it is not qualified to be ascribed a democratic system.

From a developmental perspective, Schumpeter (1942) defines the term as an "institutional arrangement in which decision-making is transferred to individuals by means of competitive struggle for peoples vote". To Odeh (2010) democracy is a technique or an arrangement by which popular participation is ensured within the civil community to decide their leaders. Underscoring the principle of participation, Onyeoziri (1989) asserted that democracy must be situated within the following cardinal points: (a) emphasis on individual and group rights and freedom (b) the point of popular and equal 
participation in collective decision (c) point of accountability by the government to the masses (d) point of equality of all citizens.

Emphasizing the elements of equality and popular participation, Abraham Lincoln, an ex-America president, conceived democracy as "the government of the people by the people and for the people" (Wada, 2004). To Seward (2004) "democracy is a system in which citizens themselves have an equally effective input into the making of binding collective decisions". From the element of accountability, Potter (2000: 368) defines democratization as a "political trend from an unaccountable government to a much more accountable government, from tradition of zero accountability to a more open tradition of accountability and openness in governance". The summation of the foregoing definitions was captured by Osaghae (1999: 5) who defines democratization as "the process of establishing, strengthening or extending the principles, mechanism and institutions that define a democratic regime".

\section{Internal Party Democracy (IPD)}

Internal party democracy is an all-inclusive phrase that is used to refer to a whole range of methods that allow and grant party members access to party deliberation and decision making (Scarrow, 2005). It was also conceived as the internal arrangement, structure, and coordination of political parties in consonance with democratic principles with direct bearing on how candidates are selected, leaders emerged, policy are made, funding is provided (Ojukwu et al., 2011). Internal party democracy has to do with the internal structural relationship within a political party; it constitutes a holistic arrangement and relationship within the three interrelated elements of political parties: party-ingovernment (PIG), party-in-the-electorate (PIE), and party-as-organization (PO) (White and Shea, 2000). Party-in-government refers to officials elected under a particular party banner. For example, all the members of the People Democratic Party (PDP) in the Senate, House of Representatives, Governors, members of the State Houses of Assembly make up the PIG. Party-in-theelectorate refers to those who attach and identify themselves to a particular party, when an average citizen in the U.S says, for instance, I'm a 'Democrat' or a 'Republican' that person is acknowledging membership in a PIE (White and Shea, 2000).

In Nigeria, it is difficult to ascertain who is a true member of a particular party. Party membership in Nigeria's case is ephemeral as people engage in the political process for selfish reasons (Liebowitz and Ibrahim, 2013). A study conducted by the International Republican Institute (IRI, 2011), indicates that only $37 \%$ of Nigerian respondents had strong confidence in parties, while $26 \%$ had no confidence at all and $35 \%$ had weak confidence in parties. The situation in Nigeria shows, without ambiguity, that party partisanship and attachment is at an abysmal level. This is confirmed by the high incidence of party defection by politicians or party representatives. Party-as-organization (PO): refers to the formal structure of the party, including party national headquarters, subnational offices, and party leaders. It is the official bureaucracy of the party, 
and it is run in the form of 'committees' in every state and in nearly every community in the nation.

\section{Political Party}

Political party can be perceived as an institutional creation by interest based individuals or groups whose ultimate aim is to capture political power. It is understood differently by several authors. It was defined by Burke (2001) as a "body of men united for promoting by their joint endeavour the national interest upon some particular principles which they are all agreed". The above definition in part is encompassing because it reiterates the concern for a particular principle, which can be inferred as a manifesto, an ideology or a distinct portrait that makes it an alternative platform for seeking power.

Neumann (1956) in his part defines political party as "an organization of society's active political agents who compete for popular support with another group or persons holding diverse views". This definition brought out the salient feature of political parties which is the competition for popular support in order to acquire power from an alternative group holding a divergent view. Summarily, political parties are regarded as a sine qua non for the organization of modern democracies as well as for the expression of political pluralism (Biezen, 2003: 1). Thus, democracy preceded political parties, but modern democracy is practically unthinkable without a well-established political party, because it serves as a medium of filtering the best candidate for an election which is the height of democratic principles.

\section{Democratic Consolidation}

Democratic consolidation, otherwise known as democratic stability, can be referred to as a premeditated and calculated political arrangement in a society by which democratic ideals gain more acceptance and legitimacy, as against sudden undemocratic act of interventions, such as military junta. In the words of Dode (2010) democratic consolidation implies "The behavioural and institutional changes that normalize democratic politics and narrow its uncertainty". Democratic consolidation is the concept and effort that is aimed at preserving new democracies from the vagaries of anti-democratic elements of the third world. Democratic consolidation was defined by Philippe (2001: 68) as the "process of transforming the accidental arrangement, prudential norms, and contingent solutions that have emerged during the transition into relations of cooperation and competition that are reliably known, regularly practiced, and voluntarily accepted by those persons or collectivities, that is, politicians and citizens that participate in democratic governance". At the heart of democratic consolidation is the erection of concrete institutions (rules) that politicians can agree upon and citizens are willing to support in a specific context. Democratic consolidation as a movement increasingly seeks to extend the life expectancy of nascent democracies through encouraging politics of 
inclusiveness, development of democratic orientation and culture, a functional civil society and political institutionalization among others.

\section{A Historical Review of Nigerian Political Parties}

Political parties of the 'third wave democracies' have their history in colonial experience and conquest. As one of the several institutions imported by the colonial masters, political parties in Nigeria can be better understood in colonial experience (Ekeh, 1972). In Nigeria, precisely, as argued by Dare (1989), political parties can be traced to the Clifford constitution of 1922 that introduced the legislative council alongside the elective principles in Lagos and Calabar. The elective principle introduced by the Clifford constitution was void of the democratic norm of equal representation. The 1922 constitution in its provisions grossly undermined the principle of proportional representation, as it only allocated one unofficial seat to Calabar and three to the whole of Lagos colony, respectively. This dysfunctional tradition of under-representation introduced into the country by the British colonial master accounts for the under-representation and exclusive politics in Nigeria. The First Republic parties - National Congress for Nigerian Citizen-NCNC in (1944), the Action Group-AG in (1948), the Northern People's Congress-NPC in (1951), and the Northern Element Progressive Union-NEPU etc, begat their history from the defective nature of the 1922 Clifford elective principle. Because the First Republic parties as noted Liebowitz and Ibrahim (2013) "constituted themselves as political expressions of ethno-regional association" which consequently influenced the character of the political parties that emerged subsequently. These dysfunctionalties ultimately led to the termination and the sudden end of the First Republic by the military.

The Second Republic was by conception never meant to last long, because it was an imposition on Nigeria by the military regime of Gen. Olusegun Obasanjo. The word imposition here is an indicative of the imposition of the five parties out of the 150 political parties announced by the Obasanjo's administration (Liebowitz and Ibrahim, 2013). Ollawa (1989) submitted that, "the weakness of the 1979 election is the decision by Federal Electoral Commission-FEDECO not to recognize any of the radical socialist parties representing alliance of ideological and issue-oriented new-breed politicians". The resultant effect was that the transition process paved way for a dominant political party (National Party of Nigeria, NPN) to emerge, a coalition of elites that emanated from the First Republic. Internal democracy and restraint was lost, as its founding fathers constituted the usual or previous Nigerian political class.

In the Second Republic, the provisions of the 1979 constitution contributed tremendously to the elimination of intra-party democracy (Liebowtz and Ibrahim, 2013). Consequently, unhealthy party competition became pervasive; almost all the parties were factionalized. And because the state was superintending over the parties, it decided which faction carried the day. Parties derived their legitimacy from the State and not from the people, and as 
a result, party leaders did not represent the interest of the citizenry but the interest of the state and its elite. Some state institutions like the Court and FEDECO became biased in their decisions, giving verdicts in favour of the faction that was recognized by the state. By 1984, the height of corruption and intra-party decay was so massive that after three months of Shagari's reelection, the only option was the termination of that republic, the return of the military.

The architect of the Third Republic and its political parties (General Ibrahim Badamosi Babangida) further demonstrated the fact that parties not founded on democratic orientation cannot outlive their founding fathers in a prospective democratic system. This was substantiated by the annulment of the presidential election in 1993 that led to the liquidation of the Third Republic and its political parties. General Babangida then, perceived the two major political parties, Social Democratic Party (SDP) and National Republican Convention (NRC) as his creation. This was possible for two reasons: he banned all the previous political parties before his administration, and he created SDP and NRC (Dode, 2010). The two political parties became institutions that were run and managed by the state, and therefore, completely subjected to the whims and caprices of the state. After the presidential election of 1993, Babangida nullified the presidential election which was a product of his administration. SDP and NRC were bereft of internal democratic ideals because they were founded by undemocratic tyrant of that era.

The Nigerian Fourth Republic was launched by the provision of the 1999 constitution. However, it is important to make a quick survey of the antecedents that led to the Fourth Republic. With the annulment of June 12, 1993 Presidential election, the unbearable political atmosphere in the country forced Ibrahim Babangida to "step aside". A decision he took on August 20, 1993. Babangida's exit prompted the emergence of Chief Shonekan's Interim National Government (ING) which was later toppled by Gen. Sani Abacha barely half a year in power.

The race to the Fourth Republic started in 1998, when Gen. A. Abubakar dissolved the five hitherto existing political parties of the Abacha's regime. And following the cancellation of all previous elections that were conducted, the ball was set rolling for another election. Under the auspices of an electoral umpire known as the 'Independent National Electoral Commission' (INEC), which granted provisional recognition to nine political associations with a proviso that any of the parties that achieved $10 \%$ of votes and above in at least 24 states of the federation after the local government elections of Dec. 5th 1998 will be accorded a substantive recognition as a political party to contest the subsequent state and federal elections. Subsequently, the following parties were successful: Alliance for Democracy (AD), All Peoples Party (APP) and People Democratic Party (PDP) were registered (Dode, 2010). The PDP won at the national and sub-national levels and did control the national government 
from 1999 to 2015 when it was defeated by an emerging All Progressive Congress (APC).

\section{Internal Governing Structures of Political Party}

For a modern representative democratic government such as Nigeria to survive, there must be formidable and well organized political parties. The study adopted the schematic indices presented by Simba (2011), to evaluate the Nigerian political parties. Simba identified the following schematics as "Internal Governing Structures" of all political parties.

Distribution of power: this has to respond to the question, where does power lie within political parties? In his analysis, Simba observed that power within the political parties should be dispersed and spread within identifiable ranks. Power should not be concentrated in the hands of a small group of people to avoid its abuse. Again, power within the parties should be restricted in the hands of parties elected leaders, because they have the mandate of the people to act on their behalf. However, the trend in Nigeria's party politics is contrary. This contradiction is attributed to the long years of military dictatorship that have negatively impacted on the democratic orientation of Nigerians and its political actors. This pattern of political orientation still has influence on party stakeholders. Consequently, it has led to party indiscipline, mutual suspicion, conflict between Party leaders and party representatives in government, as well as poor political leadership from those managing the affairs of governance. The scenario between the then Party Chairman of People's Democratic Party (PDP), Chief Audu Ogbeh and Former President Olusegun Obasanjo which led to the forceful removal of Ogbeh as the Party's National Chairman of the party was attributed to the blurred nature of power distribution within the party (Omodia, 2007). Several of similar examples abound within the parties of the Fourth Republic. The emergence of factious executives within political parties which usually ends up in dual or multiplicity of executives within party structure can also be attributed to lack of power distribution. An example is the squabble of leadership between two factions in the national leadership of All Progressive Grand Alliance (APGA). In 2014 APGA had a serious leadership tussle from it national structure on which among the two contending factions has the right to control the national structure of the party.

Mode of decision making: Top-bottom or bottom-up approach. This must be specified by the various constitutional provisions that make-up the party. This is important in the sense that, it serves as a check for imposition of candidate and other party malpractices. Especially from the grassroots, or even at the central level, this is also important as party representatives at the various levels are supposed to be sieved from the bottom as against the practice of imposition of candidates by godfathers. In Nigeria's context, the period between 1999 and 2003, when the country had only three parties: the Alliance for Democracy (AD), All People Party (APP), and Peoples Democratic Party (PDP) - was not markedly different from the previous Republics. The pattern of party 
recruitment focused on the elites who were the major financiers of the new political parties. Except, that, while AD was sectional (predominantly the South-west), the PDP and APP were more national in their spread. The second, third, and early fourth phase of the Fourth Republic saw a multiplicity of political parties in the democratic process. The PDP became a dominant party relegating other minor political parties to certain sections of the country. For example, the All Grand Progressive Alliance (APGA), Labour Party, the defunct Action Congress of Nigeria $(\mathrm{ACN})$ etc, were all zonal parties in disposition and spread (Agbaje and Adejmobi, 2007; Omodia, 2010). Consequently, decision making has been influenced by a few individuals that control parties' machineries.

Broad participation: Another cardinal point raised by Simba is that political parties must ensure broad participation in the election of its leaders. This will ensure undivided loyalty from its members and further enhance the legitimacy of party leadership. Nigeria's political parties have in their manifestoes and constitutions a comprehensive and broad base structure of participation and inclusiveness. But ironically, it is rarely translated into practice. The PDP had devised another means of choosing their leaders known as consensus. This principle is usually undemocratic, as it is shrouded in secrecy, and participation is only reserved for the top political elites in the party. PDP has on several occasions employed this method in selecting her leaders, thereby generating acrimonies within the party structure, because some elements within the party usually feel disgruntled. The 2015 general election has proven the point that any party that refuses to employ openness in its internal activities is heading for a fall. The abysmal performance by PDP in the just concluded presidential election is partly due to the lack of party internal democratic culture within the party. The PDP's presidential primary for the 2015 election was described as coronation not election. The APC had its primaries in Lagos for its presidential candidates; the PDP adopted its usual style of consensus candidate that does not give room for competitiveness.

Party Primaries: This is the direct participation of all the party members with membership cards in deciding who gets what. This model is restricted to card carrying members to avoid the problem of infiltration. Candidates are chosen at this level to represent the party in a general election. The second model is the electoral colleges; here a group of party members are selected based on some identifiable criteria to vote for candidates at the party level who will in turn represent the party in a mass election. It is also important to accentuate the fact that Nigeria's political parties tend to manifest poor representations in the conduct of party primaries, which has resulted into defection by politicians or the formation of new political parties by disgruntled party members. It can also be argued that, most of the parties are run by political patrons who have what it takes to direct the affairs of the party. This is due to their overwhelming financial capacity over the party. Thus, these party patrons or godfathers 
dictate who contest for what positions in their parties in an undemocratic manner. This party practice was noticeable in the 2015 general elections, among all the major political parties. For example, the primary that produced Ex-President Goodluck Jonathan as the presidential candidate of the People's Democratic Party (PDP) was embroiled with gross abuse of internal party democracy. The PDP compelled all other presidential aspirants to withdraw from the contest to give Jonathan the privilege of being the sole candidate of the party for the 2015 presidential election.

This does not only feature at the national level, at the sub national level for instance, in Anambra State different primaries were conducted by different factions of the PDP for the National Assembly elections where each of the factions claimed the rightful candidate for the party. In fact, the PDP was enmeshed in contentious primaries in several other states including Enugu, Oyo, Ogun, Lagos Adamawa, Imo, Taraba and Ebonyi States (The Sun, 19 December 2014). Indeed, other parties were not exempted. For instance, in Delta State, there were widespread allegations of malfeasance against the winner of the gubernatorial primary under the platform of the All Progressives Grand Alliance, as the election was marred with violence over allegations of bribing of delegates. The EU EOM (2015: 4) report captured it, thus, "the lack of an effective monitoring mechanism for internal party democratic processes for candidate nomination, and INEC's inability to reject nominated aspirants (who emerged in dubious circumstances) had negative implications for the credibility of the entire process". The inability of political parties to conduct credible primaries in Nigeria has direct implication on democratic sustainability in Nigeria. Further analysis shows that less than $6 \%$ of the PDP's candidates for 2011 general elections were women. In 2015 presidential election, of the 14 presidential candidates, only 1 was a woman and only 4 for vice presidency. This is in addition that, Both APC and PDP waved nomination fee for women. On women participation, virtually all political parties provided in their manifestoes the improvement on the lot of women. Based on this premise, it can be argued that Nigerian women who usually constitute bulk of voters, campaigns and rallies supporters are deliberately schemed out of main stream politics. But on the other hand, in recent times success has been recorded in such aspects as women involvement in politics. This is shown by the number of women appointed into government by various parties. A fairly significant number of women have been appointed ministers and political advisers at the federal level. At the state level, women have been fairly represented. It is obvious that women are completely absent in areas like the setting up of electoral guidelines, party primaries, active party membership, participation in party caucus meetings, and are rarely registered members of political parties, thus, denying them of proportionate slice of both elective and appointive offices (Simbine, 2003). The statistics for gender inclusiveness in the 2015 general election is more startling and upsetting.

Party Conference and Conventions: This should play a leading role in internalizing democracy within the party structure. Decisions at this level 
should be collective, as against the practice of consensus and imposition of candidates employed by some political parties. Party conventions make provision for a broad participation of party members from various states and regions of the country to participate once in a while on major decisions that guide the party. However, this principle is fast eroding in Nigerian party politics. Party elites decide prior to the convention 'who get what' on the guise of a consensus candidate. The 2011 PDP primaries nationwide were marked by series of anti-democratic activities, including imposition of candidates. For instance, the then Governor Gbenga Daniel of Ogun state said "the politics of imposition was responsible for instability in the polity..." He insisted that the primary election conducted by his faction was the authentic one, as against the rival faction (Ademoyega and Adesote, 2012). Gbenga alleged the primary election was monitored by INEC officials (as stipulated in section 85, subsection 2 of the Electoral Act). He concluded, "Those who did not know much about the PDP and did not participate in the primaries are now said to have won the primaries" (Lawal et al., 2011: 1).There is need for party restructuring, especially, the principle and practice that perceive the Governors as the leader of their party at the state level while at the national level the President has the final say, is inimical to the entrenchment of internal democratic values.

Level of inclusiveness: a party cannot be said to be internally democratized, when its level of inclusiveness is low or restricted to specific social groups. The socially marginalized groups such as the indigents, women and youth groups must have a place in party that claims to be internally democratic. Political parties must deliberately work out a model that will recognize the place and the contributions of these economically and politically marginalized groups. The PDP which was considered as a dominant Party until recently, despite its commitments on gender advocacy, is still rated low in the area of inclusiveness. The PDP only provided for a minimum of $15 \%$ women in party leadership position in Nigeria as of 2012, a rating far below the requirement of the National Gender Policy that made provision for 35\% (Ezeilo, 2012).

Transparency, Accountability and Institutionalization: Transparency and accountability in this context signify a high level of sincerity. This is important as it serves to check the level of suspicion and increase the level of trust within the party members. Accountability bridges the gap between party gladiators and ordinary members of a party. While institutionalization emphasizes the laid down rules and principles that guide the affairs of the party; parties in Africa are treated like personal property by their leaders and founders. In Nigeria, the Independent National Electoral Commission (INEC) has the constitutional mandate to monitor the finance and expenditure of political parties. It has the exclusive right to conduct an annual audit of the funds accrued to political parties and make public its findings in accordance to the provision in section 228 (c) of the 1999 constitution. 
There is always a serious challenge in keeping to the responsibility of monitoring the use of fund in campaign activities by INEC. For instance in 2003, the Transition Monitoring Group (TMG), an umbrella of civil society organization responsible for election monitoring, in a statement complained about the widespread bribing of delegates to influence their votes on the primaries conducted in January 2003. This was evidenced in all the parties that contested the general elections in 2003 (Adetula, 2009). In fact, it was in response to lack of transparency in PDP that made one of its presidential aspirants in 20011, Sarah Jibril, to petition the leadership of her party for gross mismanagement and misappropriation of funds. It is pertinent here to say that institutionalization can ensure that parties survive the unbridled quest of dominance by its founding fathers and leaders. The assessment by Lietbowitz and Ibrahim (2013: 34) in respect of the 2011 party's primaries reveals a scenario where party god-fathers engineered the unopposed candidacy of their surrogates. Candidates were forced to step down in preference for selected and anointed candidates mostly from party gladiators. The experience was not different in the 2015 general elections.

\section{IPD and Democratic Consolidation in the Fourth Republic}

Drawing from the history of party formation, structure and alliance in Nigeria's democracy reveals a gross defection from democratic norms. In response to the transition program of 1999, Fawole (2001) asserted thus, "the necessary behavioural commitment to the constraints of democracy was sadly absent throughout the period of the transition, as politicians and political parties operated in an anti-democratic fashion. The choice of candidates for various elections was done in a number of cases by unelected party caucuses and elders". This emphasizes the internal democratic emptiness of the political parties in the Fourth Republic from its foundation.

From 1999, political parties have crafted an unconstitutional way of resolving party internal fuss. Increasingly, politicians and party candidates have adopted the strategy of decamping, or forming a pseudo alliance as a response to internal party crisis. It is important to note that apart from the first three political parties: PDP, APP and AD founded in 1998, most of the subsequent parties that emerged were founded by individuals who were disgruntled from any of the three pioneering parties. Or a change of name, for instance, the defunct All Peoples Party (APP) that was changed to All Nigerian Peoples Party (ANPP) or a mergence as we have in APC today which is a combination of about four previous political parties. It can be inferred that the current unpleasant political scenario among Nigerian political parties can be attributed to the deficiency in internal party democracy.

The implication of this pattern of party politics is grave. For instance, the first case of party defection in the Fourth Republic was applauded by the then ruling party (PDP). Chief Evans Enwerem decamped to PDP having failed to secure the gubernatorial ticket in APP in 1999. His migration to PDP was rewarded, as he secured the senatorial ticket under the platform of the PDP and 
was later elected the senate president of the Federal Republic of Nigeria (Odum, 2002). The defection of Alhaji Atiku Abubakar a founding member of PDP and its first vice president in 2007 was attributed to the poor internal leadership style within the PDP. At the state level, Edo and Ondo states witnessed a massive defection to the party of the governors. The Ondo State House of Assembly witnesses a massive defection of PDP law makers to the Labour Party (LP), the former party of the governor (Mbah, 2011). Again dozens of law makers defected from PDP to the erstwhile ACN in Edo State, just because the incumbent governor was an ACN (Agina, 2010: 3). The point here is that, in both cases, defection was as a result of infighting within the parties. Incidence of party defection was also common among the state governors, the first scenario in the Fourth Republic was the case of Alhaji Isa Yaguda of Bauchi State, who won the governorship election on the platform of the All Nigerian Peoples Party (ANPP) in 2003, but later switched to the PDP with his supporters. Aliyu Shimkafi of Zamfara State, Saminu Turaki of Jigawa State both of (ANPP) defected to PDP while in office. Again, in November 2013, five governors, four of them from the north, defected from the PDP to the APC, they include: Abdulfatah Ahmed of Kwara (North Central), Rotimi Amaechi of Rivers (South South), Rabiu Kwankwaso of Kano (North West), Murtala Nyako of Adamawa (North East) Aliyu Wamakko of Sokoto (North West). Ample legislators, primarily from these states, followed suit: 37 representatives left the PDP for the APC in December 2013. In October 2014, former speaker of the House Aminu Tambuwal joined the APC as well as 11 Senators in January 2014 (Premium Times, January 29, 2014).

After the 2015 general elections, there was a massive movement of politicians from the crashing PDP to the rising APC across the nation. Thus, the motivation to participate in politics in Nigeria is to capture state power for private benefits. This is explainable by the pervasive intra-party squabble and defection among politicians from one party to the other seeking for political accommodation. This trend of defection shows that Nigeria's political parties are void of internal democratic values, and the political system is bereft of professional politicians who should have respect for the parties' internal guidelines. Therefore, the consequence on democratic consolidation is the weakness in democratic institutions and values as demonstrated in Nigeria.

The profound lesson here is that without a well democratically managed and institutionalized political parties, it is impossible to have surviving democratic governance. In a democratic system, intra-party democracy should be considered as an end in itself; political parties should not be considered as just a platform or medium of gaining political power, but rather as an incubator that nurture citizens' political conscience and competence. To achieve this, party's decision making process (intra-party-democracy) should be such that is accessible to individual members of the parties so that they can have a say on the general outcome. 


\section{Conclusion}

From the forgoing, it is clear that strong party system is a sine qua non for a strong and consolidating democracy. A nation's party system provides a robust avenue for citizens' participation through the electoral process. It has been equally noted that the pattern of party internal politics and arrangement can either inhibit or aggravate democratic instability. The paper reiterated the saliency of transparency, accountability, and institutionalization. The indices of party conference and convention, level of inclusiveness, party primaries and power distribution within the Nigerian political parties as weighed against Simba's schemata of internal governance structure. It is obvious that Nigeria's democracy is not consolidating as rapidly as it should, because of unhealthy democratic competition among and within the political parties orchestrated largely by lack of internal party democracy. The consequence of all these anomalies is that party politics is being played by party patrons and party godfathers.

Nigerian democracy is indeed endangered by the undemocratic activities of these party leaders. The paper concludes that, in Nigeria, the principle of internal party democracy is rarely present, and as such, democratic consolidation appears to be an illusion in the current democratic dispensation. At best, what exists under the current political system is 'civil rule' and not democracy. A deliberate effort is needed to reverse this negative trend and turn parties into instruments of democratization. It is our candid opinion that for the purpose of deepening the practice of democracy in Nigeria, emphasis and attention should be given to the activities of political parties, especially their internal affairs. The 2015 presidential election has introduced an unprecedented and historic political development in the history of Nigeria. This is a plus for democratization process in Nigeria as a seating president is defeated and voted out of office.

\section{References}

Adetula, V.A.O. (2008) Money and Politics in Nigeria. International Foundation for Electoral System IFES-Nigeria.

Agbaje, A.A. and Ojo, J. (2007) Nigeria's Ruling Party: A Complex Web of Power and Money. The South African Journal of International Affairs. Vol. 14, Issue 1.

Agina, C. (2010) "The Constitution and Monster of Defections", The Tide Wed. July 7.

Alexander, T. (2015) 'Background to Nigeria's 2015 Elections'. Centre for Strategic and International Studies. A Report of the CSIS African Program.

Biezen, I.V. (2003) Political Parties in New Democracies Party Organization in Southern and East-Central Europe. New York: Palgrave Macmillan.

Bryce, J. (1921) The American Commonwealth. London: Macmillan \& Co.

Dahl, R.A. (1971) Polyarchy: Participation and Opposition. New Haven: Yale University Press. 
Dare, L. (1989) "The 1964 Elections and the Collapse of the First Republic" in P.P. Ekeh et al. (eds.) Nigeria Since Independence The First 25 Years, Vol. V. Democracy', In Vanguard March 6-12.

Dode, O.R. (2010) Political Parties and the Prospect of Democratic Consolidation in Nigeria: 1999-2006. African Journal of Political Science and International Relation. Vol. 5.

Ekeh, P.P. (1972) Colonialism and the Two Publics in Africa: a Theoretical Statement. Comparative Studies in Fadakinte, M.M (ed.) Transition Politics in Nigeria, 1970-1999, Lagos: Malthouse Publishers, Pp. 118-134.

Fowale, A. (2000) The Problem of Democratization and Democratic Governance in Nigeria: an overview in Alade Fawole (ed.) Beyond the Transition to Civil Rule Consolidating Democracy in Post Military Nigeria MAOBIC Press Ltd. Hamilton to the Information Age. New York: Bedford/St. Martin's 14.

Liebowitz, J. and Ibrahim, J. (2013) A Capacity Assessment of Nigerian Political Parties. NNDP Nigeria.

Mbah, P. (2011) Party defection and Democratic Consolidation in Nigeria, 1999-2009. Afro Asian Journal of Social Sciences, 2(23)

Odum, F. (2002) Decamping and the Fruit of Fair, Weather Politics www.nigerdeltercongress.com/dartide/decamping.

Ogunsanwo, A. (2015) Slaying of the Supreme Commander: A Sine Qua None for Nigeria's Development and Progress? In Honour of Akande, M.A. Splash 105.5 FM.

Omodia, S.M. (2010) political parties and party politics in the Nigerian Fourth Republic. Trakia Journal of Sciences, 8(3): 65-69.

Omodia, S.M (2007) Party Politics and Political Development in Nasarawa State, Nigeria: A Focus on the Nigerian Fourth Republic. Journal of Social and Development. (1): 40-46.

Omotola, J.S. (2009) Nigerian Parties and Political Ideology. Journal of Alternative Perspectives in the Social Science. 1(3): 612.

Onapajo, H. (2015) How Credible Were the Nigerian 2015 General Elections? An "Electoral Integrity" Framework of Analysis.

Osaghae, E.E. (1998) Crippled Giant: Nigeria Since independence. London: Hurst and Company.

Plilippe, C.S. (2001) Parties Are Not What They Once Were, In Gunther, R. and Diamond L. political parties and democracy. The Tohn Hopskins University Press.

Potter, D. (2000) "Democratization, Good Governance and Development". In Allen, T. and Thomas, A. (eds.) Poverty and Development into the 21st Century, UK: The Open University and Oxford University Press.

Schumpeter, J. (1942) Capitalism, Socialism and Democracy. London: Routled. 
Simba, S.K. (2011) Internal Governance Structures of Political Parties in Democratic Governance Paper Presented at the1st EAC Consultative Meeting for Political Parties in East Africa held 15-16th September in Nairobi Kenya.

Scarrow, S. (2005) Political Parties and Democracy in Theoretical and Practical Perspectives. National democratic Institutes for International Affairs Washington DC.

Thomas, A. (eds.) Poverty and Development into the 21st Century, U.K: The Open University and Oxford University Press.

White, J.K. and Shea, D.M. (2000) New Party Politics: From Jefferson and Hamilton to the Information Age. New York: Bedford/St. Martin's 14.

Yaqub, N. (2002) "Political Parties and the Transition Process", In Onuoha, B. and Fadakinte, M.M. (eds.) Transition Politics in Nigeria. 1970-1999, Lagos: Malthouse Publishers, Pp.118-134. 